\section{TEACHING ORGANIC AND BIOLOGICAL CHEMISTRY TO NURSING STUDENTS}

\section{Introduction}

Although Biochemical Education has included over 10 articles on the problems of teaching biochemistry to medical students, including a summary of the 1974 Nuffield Foundation discussions ${ }^{1}$, only one paper has dealt with a different group of health-science students: a course for dental students has been described ${ }^{2}$. Yet there are many of us who must teach organic and biological biological chemistry to university students in other health-oriented programs, such as nursing, medical technology, dental hygiene, and pharmacy. These and other programs require a course in bioorganic chemistry, which is often seen by the students as a difficult and professionally-irrelevant hurdle in their attaining the bachelor's degree. Too often such courses have been unpleasant for both the students and the teacher. This paper describes a new course designed for 250 second-year nursing students at the University of Michigan. The course was accepted by the students as both enjoyable and relevant to their career goals.

\section{Content and Philosophy of the Course}

Table I outlines the topics for lectures ( 3 days per week for 1 hour) which covered the basic principles of organic and biological chemistry. The students had taken one term of college inorganic chemistry as a prerequisite, and this was to be their last chemistry course. Thus the primary concern was to impart to these students the knowledge that life in general and medicine in particular is based on biochemistry.

Nurses do not need to be experts in bio-organic chemistry. They were not asked to memorize structures or pathways, but rather to understand names and processes important to medicine. They did not do kinetic nor thermodynamic calculations nor did they have a laboratory in biochemistry; their experience from inorganic chemistry and microbiology laboratories was considered sufficient. What nurses should know are the general principles of biochemical structure and function. They were asked to recognize and name organic functional groups in biological molecules, including drugs and vitamins. The students were taught the composition of carbohydrates, lipids, proteins, and nucleic acids; the pathways by which these compounds are digested and used for body growth; and the products which are excreted. The course covered most areas of traditional biochemistry in a superficial but modern way, stressing our knowledge about selected genetic diseases (see Table I).

\section{Format of the Course}

Detailed outlines were distributed at the beginning of each lecture, which made note-taking and even attendance unnecessary. However, almost all students did attend and added notes to the outlines. The lectures proceeded leisurely, allowing frequent pauses to answer any questions or to solicit student comments. Occasional movies and frequent examinations based on the lecture outlines (see Table II) helped to provide variety and reinforcement of ideas. Grading was on a fixed scale, thus eliminating the arguments with the teacher and the competition between students which occur during use of a "curved" scale.

In addition, sections of $\mathbf{3 5}$ to $\mathbf{4 0}$ students met once a week with graduate teaching assistants, who answered questions, reviewed lectures, administered quizzes, and provided individual tutoring when needed. One session was spent doing clinical dipstick tests, followed by a tour of the clinical laboratory. A further incentive to learn more biochemistry was allowing the students to raise their quiz grades by submitting reports on biochemical topics of their own choosing (see Table II)

\section{Response of the Students}

Beyond the aspects of organizing a well-structured bio-organic course relevant to nursing, most important to the success of the

\section{ALAN R. PRICE}

Associate Professor

Dept. of Biological Chemistry

University of Michigan

Ann Arbor, Michigan, 48104,

U.S.A.

course were the efforts to tell the students that the staff enjoyed teaching them and really cared that they learn biochemistry. Like most health-related students, the nurses were young (although some returning registered nurses were 30 to 55 years old), interested, warm, friendly, and appreciative - but only if we treated them as individuals and demonstrated our willingness to help them.

Photographs were obtained from the School of Nursing and an attempt was made to learn some of the students' names, especially those who asked the most questions during lectures (so they could be called on by their first names). A daily suggestion box was kept in the lecture hall. It appears that an important aspect of making a large lecture course for young students seem "personal" (Table III) is the professor's willingness to display his personality openly and to be sensitive to the student's need to feel important and unique.

Table I

\section{Lecture topics for a bio-organic chemistry course for nursing students}

Topic Hours

Introduction to course and inorganic chemistry review 1

Organic chemistry (using drugs and pollutants as examples):

alkanes, alkenes, alkynes, and aromatic hydrocarbons; isomers

alcohols, halides, thiols, ethers, aldehydes, ketones, amines, acids and their derivatives

review and exam I

Biological structures:

optical isomers; introduction to biochemistry carbohydrates: sugars and polymers

lipids: fatty acids and derivatives, steroids (including vitamins and hormones)

proteins: amino acids classification, conformation, peptide hormones, hemoglobin and sickle cell anemia, enzymes and coenzymes

nucleotides and nucleic acids review and exam II

Metabolism:

digestion of food macromolecules; lactase deficiency carbohydrates: blood glucose and diabetes, glycogenesis and glycogenolysis, cyclic-AMP and hormones, glycolysis, galactosemia, muscle contraction, Krebs' cycle and respiratory chain

lipids: synthesis and degradation, diabetes, atherosclerosis, clinical lab tests

review and exam III

clinical laboratory tour

amino acid metabolism, urea, phenylketonuria

nucleic acids: nucleotide metabolism, Lesch-Nyhan

syndrome and aminocentesis, DNA synthesis, RNA synthesis and drugs, protein synthesis and the genetic code, mutations, viruses

antibodies, multiple myeloma, interferons; blood group substances and erythroblastosis fetalis

review, questionnaire, and final exam 
As evidence for the success of the course, the following can be cited:

(1) the basic material, which was believed by the course staff to be important to the students' careers, was learned well enough by the nurses to get good exam scores (Table II);

(2) over $90 \%$ of the students enjoyed the course and found it relevant to nursing (Table III), and the School of Nursing faculty agreed; and

(3) the University gave me one of the 1973 Distinguished Service Awards for' my 3 years' work on this course. Such an approach to the teaching of biochemistry can be heartily recommended for all health-oriented undergraduates.

\section{Table II}

\section{Learning aids for the bio-organic course for nursing students}

Textbook: Elements of General and Biological Chemistry, John R. Holum, 3rd Ed. (1972), Wiley and Sons, Somerset, New Jersey.

Program: Introduction to Formulas and Classification of Organic Compounds, Lila Miller (1970), produced locally.

Movies: Hydrocarbons and their Structure (1962) Coronet, Chicago.

Biochemistry and Molecular Structure (1964) Modern Learning Aids, Rochester, New York.

Muscle: Chemistry of Contraction (1969) Encyclopedia Britannica Educational Corp., Chicago.

DNA: Molecule of Heredity (1960) Encyclopedia Britannica Educational Corp., Chicago.

Gene Action (1963) Encyclopedia Britannica Educational Corp., Chicago.

Viruses: Threshold of Life (1967) Coronet, Chicago.

Clinical Clinitest, Ketodiastix, Bili-Labstix, and Dextrostrix for Tests: detection of glucose and ketone bodies in the students' own urine and blood, Ames Company, Elkhardt, Indiana.

Clinical Visit to the University Hospital's Test Panel Laboratory Tour: to see clinical blood testing on the Autoanalyzer.

Grading: $\quad 90-100 \%$ correct $=A, 80-90 \%=B, 70-80 \%=C$, $60-70 \%=\mathrm{D}$, and below $60 \%=\mathrm{E}$ (failure). Grades for the course were calculated from the best 3 of 4 exam scores $(90 \%)$ plus the adjusted quiz grade $(\mathbf{1 0 \%})$. Typical final grades for the course were $38 \%$ A, 38\% $\mathrm{B}, 20 \% \mathrm{C}, 4 \% \mathrm{D}$, and $0-1 \% \mathrm{E}$ for 250 students.

Exams: 4 hourly exams of 50 multiple-choice questions each were machine-graded for percent correct. Typical exam grades were $27 \% \mathrm{~A}, 35 \% \mathrm{~B}, 22 \% \mathrm{C}, 10 \% \mathrm{D}$, and $6 \% \mathrm{E}$. The mean exam score was usually $81 \%$ correct with a standard deviation of $11 \%$. The exams and answer keys were returned and discussed with the students.

Quizzes: 8 weekly quizzes (between exams) of 10 multiple-choice questions each were taken on self-scoring answer sheets, which require the student to continue selecting until the correct answer is found (Z12 Trainer-Tester sheets from van Valkenburgh, Nooger, and Neville, Inc., New York).

Reports: Absences or any quiz points missed could be made up by writing one-page reports on a current biochemical topic. Many students selected from a list of over 200 Scientific American magazine articles relevant to biochemistry. Each report counted 25 to $50 \%$ of the value of one quiz.

\section{REFERENCES}

1 "Teaching Biochemistry to Medical Students." Biochemical Education 3: 3-7, 23-28 (1975).

2 Beeley, J. A. "The Teaching of Biochemistry to Dentai Students." Biochemical Education 2: 9-11 (1974).

\section{ACKNOWLEDGEMENTS}

I thank Dr. George Geis' 1970 ESSO Foundation project at the University of Michigan Center for Research on Learning and Teaching, where I was introduced to the design of courses based on the students' career goals. The current head of the bio-organic course for nurses is Dr. Thomas R. Riggs.

Table III

Student responses to the bio-organic course for nurses

\section{Response $(\%)^{*}$}

Question

S.A. A. D. S.D. N.o.

The lecture outlines are useful and should be continued.

I found it was not necessary to attend lectures.

The suggestion box is a silly idea and should be removed.* *

The discussion sections were useful.

This class is too impersonal.

The exams were fair and covered the material well.

Knowing the percent correct I needed to attain a certain grade gave me an extra incentive to try harder.

I wish there had been a weekly 3-hour laboratory.

This biochemistry course is relevant to nursing.

I liked this biochemistry course.

$\begin{array}{rrrrr}95 & 4 & 1 & 0 & 0 \\ 3 & 5 & 31 & 58 & 3 \\ & & & & \\ 0 & 3 & 44 & 47 & 6 \\ 23 & 49 & 18 & 8 & 2 \\ 2 & 5 & 53 & 31 & 9 \\ & & & & \\ 50 & 45 & 3 & 1 & 1 \\ & & & & \\ 35 & 39 & 17 & 4 & 5 \\ & & & & \\ 1 & 2 & 13 & 83 & 1 \\ 53 & 43 & 2 & 1 & 1 \\ 60 & 30 & 6 & 1 & 3\end{array}$

*The students were required to complete a signed questionnaire consisting of 50 items like those above (over $99 \%$ of the students responded). Code: $\mathrm{S} . \mathrm{A} .=$ strongly agree, $\mathrm{A} .=$ agree, $\mathrm{D} .=$ disagree, S.D. = strongly disagree, and N.O. = no opinion. In addition, they were asked to make unsigned criticisms of the course. Selected, representative comments follow:

"Having transferred to the School of Nursing after 3 years in the Liberal Arts College, I consider this one of the best courses I've had at the University. The course was wonderfully organized and goaldirected, and the emphases placed on each unit were valuable and seemed to stress the most important material in a coherent and understandable manner."

"I really did enjoy the lectures and felt I learned a lot. The way you seemed to care about everyone as an individual made this class unique."

"So much of what l've always done as a registered nurse really makes sense now. I hope I can remember all you've taught me so that I can explain it to others."

* *Yet, while some constructive criticisms and ideas for improving the course were submitted, most of the notes were of the type: "I like your tie ... shirt ... haircut ... dimples ... etc." 